\title{
A BIBLIOTECA, O NACIONAL E A MODERNIDADE NA BELLE ÉPOQUE CARIOCA
}

\author{
Carlos Henrique Juvêncio \\ Doutorado em Ciências da Informação pela Universidade \\ de Brasília, Brasil. Professor Adjunto da Universidade \\ Federal Fluminense, Rio de Janeiro, Brasil. \\ carloshjuv@gmail.com. \\ https://orcid.org/0000-0003-2376-4823.
}

\begin{abstract}
RESUMO
O final do século XIX e o início do século XX representam para o Rio de Janeiro e para o Brasil um momento de profundas transformações políticas, sociais e urbanas. Num contexto de intensa agitação político-social graças à Proclamação da República, a Biblioteca Nacional emerge como uma das grandes beneficiadas dos movimentos de modernização da antiga capital do país. Este artigo objetiva compreender como a Biblioteca Nacional se tornou símbolo da Primeira República e nela se ancora a consagração do regime republicano. Posiciona a BN como um espaço representante do moderno, seja em suas práticas, em sua arquitetura ou no capital social que acumula ao seu redor. Concluí que a Biblioteca Nacional exerce o seu papel de guardiã da memória nacional, além de oferecer o moderno através de seus produtos e serviços e de ser um polo de erudição em busca do desejo de civilização e modernidade da Primeira República.
\end{abstract}

Palavras-chave: Biblioteca Nacional. História das Bibliotecas. História do Brasil. Memória. Primeira República.

THE LIBRARY, THE NATIONAL AND MODERNITY IN CARIOCA'S BELLE ÉPOQUE

\section{ABSTRACT}

The end of the 19th century and the beginning of the 20th century represent a moment of profound political, social and urban transformations for Rio de Janeiro and for Brazil. In a context of intense political and social agitation in the face of the Proclamation of the Republic, the National Library emerges as one of the great beneficiaries of the modernization movement in the country's former capital. This article aims to understand how the National Library became a symbol of the First Republic and the consecration of the republican regime is anchored there. It positions the National Library as a space that represents the modern, whether in its practices, architecture or in the social capital it accumulates around it. Concluded that the National Library exercises its role as guardian of the national memory, in addition to offering the modern through its products and services and being a pole of scholarship in search of the desire for civilization and modernity of the First Republic.

Keywords: National Library. History of Libraries. History of Brazil. Memory. First Republic.

Recebido em: 09/11/2020

Aceito em: 03/02/2021

Publicado em: 12/07/2021

\section{INTRODUÇÃO 1}

Os primeiros decênios do século XX no mundo ocidental são denominados Belle Époque, período de grandes transformações urbanas e agitações político-sociais, tendo como pano de fundo as revoluções tecnológicas que surgem, como o cinema, o telégrafo, o telefone e o automóvel, sobretudo na Europa (BORGES, 2020). No Brasil e em especial no Rio de Janeiro, capital do país à época, o cenário é o mesmo, mas a tais acontecimentos

${ }_{1}^{1}$ De forma a manter a fidedignidade dos textos, optamos por não atualizar os vocábulos nas transcrições diretas de textos. 
são adicionados as implicações de uma República recém-proclamada, que buscava se firmar e fortalecer a concepção de Nação brasileira, sobretudo pelo uso dos símbolos e da doutrina do Positivismo Comtiano, ao mesmo tempo em que enfrentava inúmeras revoltas e forte oposição e contestação de setores das elites descontentes com a perda de poder que experimentavam (ENDERS, 2014).

Em meio a tudo isso, a então capital do país passa por uma de suas maiores transformações urbanas e de sua paisagem natural. Pereira Passos, prefeito do Rio, comanda a derrubada do casario centenário do centro e o início do arrasamento do Morro do Castelo, um dos primeiros núcleos da habitação da cidade.

Para a Biblioteca Nacional (BN), àquela época comandada por Manoel Cícero Peregrino da Silva ${ }^{2}$, apadrinhado político de Epitácio Pessoa ${ }^{3}$, ministro da Justiça e Negócios Interiores, a abertura da Avenida Central era a oportunidade para realizar um dos seus mais antigos desejos: um prédio próprio, projetado especialmente para si.

Uma biblioteca nacional deveria representar a Nação, nela estão depositados os tesouros intelectuais mais relevantes para aquele povo e, por isso, merece um prédio que represente a magnitude de seu acervo. Sob essa bandeira, Peregrino da Silva, que assumira a Instituição em 1900, viu um terreno ser reservado à Nacional e a sua pedra fundamental ser lançada em 1905. A obra foi concluída em 1910 e, em 29 de outubro daquele ano, exatamente um século após sua fundação em solo brasileiro, a BN tinha seu novo prédio inaugurado.

Este artigo objetiva compreender como a Biblioteca Nacional se torna símbolo da Primeira República e nela se ancora a consagração do regime republicano, posicionando-a como um espaço representante do moderno, seja em suas práticas, em sua arquitetura ou no capital social que acumula ao seu redor. Nosso intuito é evidenciar como ela serve

\footnotetext{
${ }^{2}$ Manoel Cícero Peregrino da Silva nasceu em 7 de setembro de 1866, na cidade de Recife (PE) e faleceu em 3 de outubro de 1956 na então capital do país, o Rio de Janeiro. Formado em Direito, durante seus mais de 50 anos de atividade profissional atuou em campos diversos a este, sendo, por exemplo, prefeito interino e diretor geral da Instrução Pública do então Distrito Federal; diretor da Biblioteca da Faculdade de Direito de Recife e Reitor da Universidade do Rio de Janeiro. Contudo, seu papel de maior destaque foi como diretor da Biblioteca Nacional brasileira (BN), instituição da qual esteve à frente durante 24 anos, entre 1900 e 1924 (JUVÊNCIO, 2016).

${ }^{3}$ Advogado, bacharel pela Faculdade de Direito do Recife (1886), nasceu na cidade de Umbuzeiro, no estado da Paraíba, em 23 de maio de 1865. [...] Foi deputado à Assembléia Nacional Constituinte (1890-1891) e deputado federal (1891-1893) [...]. Foi ainda ministro da Justiça e Negócios Interiores (1898-1901). [...] Por meio de eleição direta, assumiu a presidência em 28 de julho de 1919. Após o cumprimento do período presidencial, foi senador pela Paraíba e membro da Corte Permanente de Justiça Internacional de Haia (1923-1930). [...] Faleceu na cidade de Petrópolis, estado do Rio de Janeiro, em 13 de fevereiro de 1942 (BIBLIOTECA DA PRESIDÊNCIA DA REPÚBLICA, C2015).
} 
aos propósitos de formação de uma identidade nacional e preservação da memória desejada pelos republicanos.

Sob este prisma, utilizaremos como referencial teórico Bessone (1999), Bittencourt (1955), Carvalho (2011), Fonseca (1973), Gomes (1983), Neves (2003) e Schwartzman (2001). Além deles, utilizaremos os relatórios de gestão escritos por Peregrino da Silva e publicações do período. Contudo, convém ressaltar a dificuldade de encontrar estudos e textos que se dediquem às bibliotecas do período.

Ademais, articulamos três dimensões ao moderno que a Biblioteca Nacional representava: seu novo espaço, projetado para abrigar uma biblioteca, ao invés dos locais adaptados em que foi alocada entre 1810 e 1910; seu acervo, partindo da aplicação das técnicas biblioteconômicas até os serviços oferecidos pela Instituição; e, por fim, a Instituição como símbolo e reunião do moderno ao tecer entorno de si uma rede intelectual de construção e discussão científica.

\section{O BRASIL MODERNO DO RIO DE JANEIRO: ENTRE CAFÉS E LIVROS}

$O$ início do século $X X$ marca um período de profundas transformações no cenário urbano da então capital do Brasil, o Rio de Janeiro. A República, que fora proclamada apenas uma década antes, difundia a ideia de que o legado português era o responsável pelo atraso do país, mesmo Dom Pedro II, brasileiro nato, era visto como uma herança indesejada dos tempos de colônia, daí a vontade de se afastar, cada vez mais, dessas referências. Ademais, no campo dos símbolos, os positivistas, que foram bastante atuantes em prol da República, buscavam ressignificar os símbolos pátrios, forjando uma identidade genuinamente brasileira em detrimento da portuguesa (KOK, 2005; NEVES, 2003).

Nesse contexto:

[...] é preciso lembrar o papel simbólico que o Rio assume como cidade-capital: reformada, iluminada, saneada e modernizada, a capital permitia aos estrangeiros que nela aportavam, aos que circulavam pelas calçadas da grande Avenida vestidos pelo último figurino parisiense e aos líderes da República acreditar que o Brasil - nela metonimizado - havia finalmente ingressado na era do progresso e da civilização. Para o país como um todo, os estados - para utilizar a fórmula de Campos Sales -, a capital modernizada antecipava um futuro que imaginavam que um dia seria o seu (NEVES, 2003, p.40-41). 
De fato, o progresso, lema tão caro à doutrina positivista, presente na bandeira nacional, é o mote de ação da Primeira República, ao moderno o país seria alçado após a sua proclamação e as mudanças que ela implementava na capital.

Pereira Passos ${ }^{4}$, prefeito do Distrito Federal, o Rio de Janeiro, seleciona vários pontos para modificar a cidade e modernizá-la, e como símbolo do atraso elegeu o casario colonial que constituía boa parte do centro da cidade, transmutados em cortiços onde, segundo ele e seus contemporâneos, a aglomeração e péssimas condições de higiene favoreciam a proliferação de doenças e rendiam à cidade o infame título de "túmulo dos estrangeiros", já que doenças como febre amarela, tifo, tuberculose e difteria assombravam seus residentes e, sobretudo, seus visitantes (KOK, 2005; PALMA, [200-]).

O eleito para comandar as ações higienistas fora Oswaldo $\mathrm{Cruz}^{5}$, sanitarista que alcançava fama mundial, à época, por seus estudos sobre diversas doenças tropicais e sobre sanitarização dos espaços. Sob o argumento de salubridade e arejamento do centro do Rio, várias ações começaram a ser tomadas com relação às centenárias construções, sendo o mais drástico a derrubada de centenas delas, onde passaria a ser a Avenida Central, ícone da modernidade tão desejada pelos dirigentes à época (PALMA, [200-]).

Tal avenida, entusiasmada pela moderna Paris, alvo de inspirações por parte dos dirigentes republicanos, era o símbolo maior da modernidade que se buscava e por que ansiava o país, por onde se desfilavam as últimas modas e os fraques mais imponentes (BARRETO, 2017).

\footnotetext{
${ }^{4}$ Bacharel em sciencias physicas e mathematicas e engenheiro civil, desempenhou muitas commissões importantes do governo, sendo por muitos annos director da actual estrada de ferro Central do Brazil ; esteve em Inglaterra commissionado pelo governo, e ultimamente tem estado na direcção de varias emprezas de viação ferrea, como na estrada de Macahé a Campos, na do Cosme Velho ao Corcovado e na companhia ferro-carril de S. Christovão. É sócio fundador do Instituto polytecnico brazileiro; é da associação promotora da instrucção, etc. [...]" (SACRAMENTO BLAKE, 1895, p.89-90).

5 Oswaldo Cruz nasceu no dia 5 de agosto de 1872, em São Luís de Paraitinga, São Paulo.[...] Aos 15 anos, ingressou na Faculdade de Medicina do Rio de Janeiro. Antes de concluir o curso, já publicara dois artigos sobre microbiologia na revista Brasil Médico. [...] em 1896 pôde realizar o seu sonho: especializar-se em Bacteriologia no Instituto Pasteur de Paris, que, na época, reunia grandes nomes da ciência.

Ao voltar da Europa, Oswaldo Cruz encontrou o Porto de Santos assolado por violenta epidemia de peste bubônica, e logo se engajou no combate à doença. Para fabricar o soro antipestoso, foi criado, em 25 de maio de 1900, o Instituto Soroterápico Federal, instalado na antiga Fazenda de Manguinhos, tendo como diretor geral o Barão de Pedro Afonso e diretor técnico o jovem bacteriologista. Em 1902, Cruz assumiu a direção geral do novo Instituto. [...]

Em 1909, deixou a Diretoria Geral de Saúde Pública, passando a se dedicar apenas ao Instituto de Manguinhos, que fora rebatizado com o seu nome. Do Instituto lançou importantes expedições científicas que possibilitaram a ocupação do interior do país. Erradicou a febre amarela no Pará e realizou a campanha de saneamento da Amazônia. Permitiu, também, o término das obras da Estrada de Ferro Madeira-Mamoré, cuja construção havia sido interrompida pelo grande número de mortes entre os operários, provocadas pela malária.

[...] Sofrendo de crise de insuficiência renal, morreu a 11 de fevereiro de 1917, com apenas 44 anos (FUNDAÇÃO OSWALDO CRUZ, C2000).
} 
Ainda no bojo de tais ações, figura a derrubada do Morro do Castelo, espécie de certidão de nascimento da cidade de São Sebastião do Rio de Janeiro, já que, desde o século XVI, a cidade vinha se desenvolvendo em suas ladeiras e aos seus pés. De fato, debate-se se a sua derrubada não teve relação com o desejo de se afastarem, de vez, traços urbanísticos de herança portuguesa, vinculados ao atraso e à submissão do país nos séculos anteriores, ao invés da noção de arejamento e de salubridade da cidade (CARVALHO, 2011).

Mas não só de mudanças urbanas vive a cidade, era necessário, ainda, segundo os modelos parisienses, criar instituições que abrigassem a elite do país, que desejava se sentir nos salões europeus. A Confeitaria Colombo, criada em 1894, era um desses espaços, onde a gens de lettre se reunia para discutir assuntos da política nacional, além de literatura e outros assuntos de interesse científico. O café era um espaço de troca e construção.

Schwartzman (2001) alerta que, na ausência das universidades, eram cafés, grêmios, sociedades científicas, livrarias, bibliotecas e museus espaços de construção e discussão científica. Nos salões da Colombo, discutiam-se as teorias modernas à época das ciências sociais, das novas teorias que surgiam e dos inventos que passavam a ocupar espaço nas grandes cidades, como o automóvel e o cinema. Outro local de sociabilidade era a Academia Brasileira de Letras (ABL), onde, liderados por Machado de Assis, os intelectuais do período discutiam, desde 1896, ano de sua fundação, a língua e a literatura nacional, ocupando-se das agitações políticas dos primeiros anos da República (BESSSONE, 1999).

Se o livro era o que os unia, juntavam-se aos espaços de sociabilidade as livrarias, locais para onde a elite intelectual do período confluía em busca do moderno em termos de produção escrita, seja literária ou científica, sobretudo do exterior. A esse movimento de intelectuais e sua intrincada rede de relações, Angel Rama (1985) chama de "cidade das letras". Bessone (1999, p.113, grifo nosso) alerta que:

Parte desses letrados constituía potencialmente [...] o círculo de leitores que se identificavam por interesses afins, ampliando a efervescência cultural da cidade por meio do consumo de livros e jornais, valorizando a bibliofilia, o comércio de livros, constituindo bibliotecas, criando grupos formais e informais de leitores.

De fato, dentre os espaços de sociabilidade que alcançam um novo patamar, no final do Império e início da República, podemos perceber que as bibliotecas, mesmo em meio 
a uma população eminentemente analfabeta - cerca de $75 \%$ das pessoas não sabiam ler e/ou escrever -, ouriçou a classe intelectual do período a usá-las como espaço de discussão, de construção do saber e de acesso à informação (BESSONE, 1999).

Logo, elas têm papel de relevância na construção política, social e científica do país, seu número, atualização do acervo e importância são elementos de destaque. Podemos depreender, então, que a intenção da grande reforma sofrida pela Biblioteca Nacional, no início do século XX, era servir de expoente do processo modernizador pelo qual a Capital do país passava, mas servir, também, a essa cidade das letras, que se desenvolvia ao seu redor. Muito além de ser a Paris nos Trópicos (BESSONE, 1999), a reforma intentava ser um meio de demonstrar que o país era tão avançado quanto os europeus e que poderia sim, haver um polo cultural e intelectual nas ex-colônias.

Dessa forma, "As bibliotecas de uso público, instaladas no Rio de Janeiro, ampliadas na passagem do século XIX para o XX, tornaram menos árida a existência daqueles que puderam usufruir de seus recursos", mesmo "Não tão ricas nem sofisticadas quanto suas congêneres européias, eram importantes dentro das limitações a que estavam sujeitas, oferecendo possibilidades de atualização aos seus leitores, discretos, em uma sociedade com tão alto índice de analfabetismo" (BESSONE, 1999, p.178).

Porém, graças à vulgarização do jornal e dos livros, experimentada desde a fundação da Imprensa Régia, em 1808, o número de leitores estava em franca ascensão no país e, por conseguinte, o número de usuários das bibliotecas, ao passo que, em 1910, conforme Bessone (1999), a Capital contava com grandes bibliotecas abertas ao público ${ }^{6}$, dentre elas a Biblioteca Nacional, o Real Gabinete Português de Leitura, a Biblioteca Fluminense, a Biblioteca da Faculdade de Medicina, a Biblioteca da Marinha e a Biblioteca do Exército.

Assim, as bibliotecas buscavam aumentar seu horário de funcionamento e oferecer melhores condições para o atendimento de seu público, além de ampliar seu acervo com novas aquisições. Um bom exemplo, segundo Bessone (1999), é a Biblioteca Nacional que, entre 1892 e 1904, tem um índice de crescimento do seu acervo na casa de $500 \%{ }^{7}$, já o Almanak Laemmert, em 1893, anuncia:

\footnotetext{
6 Consideramos importante ressaltar que o fato de a biblioteca ser franqueada ao público não implica, necessariamente, que ela seja uma instituição pública, a título de exemplo, a Biblioteca Fluminense e o Gabinete Português de Leitura são/eram instituição privadas, mas que permitiam o acesso do público em geral, mediante a observação de certas normas, tais como de vestuário.

$7 \mathrm{O}$ acervo da Biblioteca Nacional salta de pouco mais de 130 mil itens, em 1892, para mais de 670 mil em 1904.
} 
Está aberta todos os dias uteis, desde ás 10 horas da manhã atpe ás 9 da noite sem interrupção.

Durante o expediente, das 9 ás 9 horas da boite, é illuminada a luz electrica por lampadas incandescentes.

São admitidas todas as pessoas que se apresentarem decentemente vestidas. Presta-se-lhes os livros existentes que pedirm, e bem assim papel e lapis para tomarem qualquer apontamento (LAEMMERT, 1893).

Logo "[...] Uma biblioteca considerada como um laboratório não pode, é evidente, permanecer isolada, como se ela acumulasse, de modo maníaco, erudito e culto, milhões de signos. Ela serve antes de estação de triagem, de banco [...]" (LATOUR, 2008, p.37). Assim, as bibliotecas podem ser vistas como centros de erudição e de cultura para onde convergem os intelectuais.

Em virtude do burburinho das livrarias e da paz encontrada em algumas bibliotecas públicas, o Rio de Janeiro pôde vangloriar-se de ter boas opções de vida cultural, mesmo com as óbvias restrições às mais exageradas pretensões de alguns em transformar a cidade numa espécie de Paris na América (BESSONE, 1999, p.177).

Dessa forma, se as bibliotecas experimentam um grande crescimento durante a Primeira República, elas, na verdade, faziam-no seguindo o modelo da Europa e, sobretudo, da França, já que eram o arquétipo de sociedade perfeita a ser seguida pela Primeira República. Ademais, buscavam servir apenas à elite letrada, tornando-se, em sua maioria, repositórios passivos do saber, sem participação ativa na promoção da cultura nacional, ou no incentivo a ela.

Assim, as transformações sofridas pela Biblioteca Nacional, no início do século XX, são um reflexo das políticas nacionais de modernização do Estado e de suas instituições, bem como uma resposta às demandas da elite intelectual do período, que buscava espaços alternativos de discussão dada a ausência de universidades.

\section{ENTRE O MODERNO E A NAÇÃO: A BIBLIOTECA NACIONAL ENTRE 1900 E 1920}

Bittencourt (1955) observa que Peregrino da Silva reuniu ao redor de si e da BN a nata intelectual da Capital, fazendo que discussões de interesse nacional fossem realizadas na Instituição e essa apoiasse as ações do governo. Um exemplo pode ser encontrado nos diversos processos que envolvem as questões de limites dos territórios brasileiros, em que o acervo da Biblioteca, segundo o autor, serviu de base para que os representantes brasileiros nas cortes arbitrais ganhassem diversas causas em prol do país. 
Em 1907, Peregrino da Silva inicia a remodelação da Biblioteca Nacional, fazendo uma viagem à Europa e aos Estados Unidos, buscando ver o que de mais moderno se fazia (BITTENCOURT, 1955), ocasião em que visita as bibliotecas do Congresso Americano, de Nova lorque, de Leipzig, do Vaticano e de Paris, o Arquivo de Marinha e Ultramar da Biblioteca de Lisboa, o Arquivo e Biblioteca de Haia, o Museu de Amsterdã e o Instituto Internacional de Bibliografia, em Bruxelas. Nessas instituições, observa o trabalho, a arquitetura e os espaços, vendo in loco o que de moderno se fazia e construía (JUVÊNCIO, 2016).

Nesse bojo, incorpora elementos arquitetônicos ao novo prédio, como o mobiliário de aço, e também dá atenção às técnicas aplicadas pelas instituições no tratamento e conservação de seus acervos. A título de exemplo, podemos citar a introdução do Book-Carrier (Figura 1), uma espécie de elevador que carregava os livros dos depósitos da Biblioteca até ao salão de consulta, evidenciando o moderno aparato tecnológico que a instituição detinha. Além dele, a BN foi uma das primeiras instituições públicas do país a contar com um sistema de telefonia e a primeira a adotar o uso da máquina de escrever (SILVA, 1913; FONSECA, 1973).

Figura 1 - Mecanismo do book-carrier.

Fonte: Biblioteca Nacional (1911).

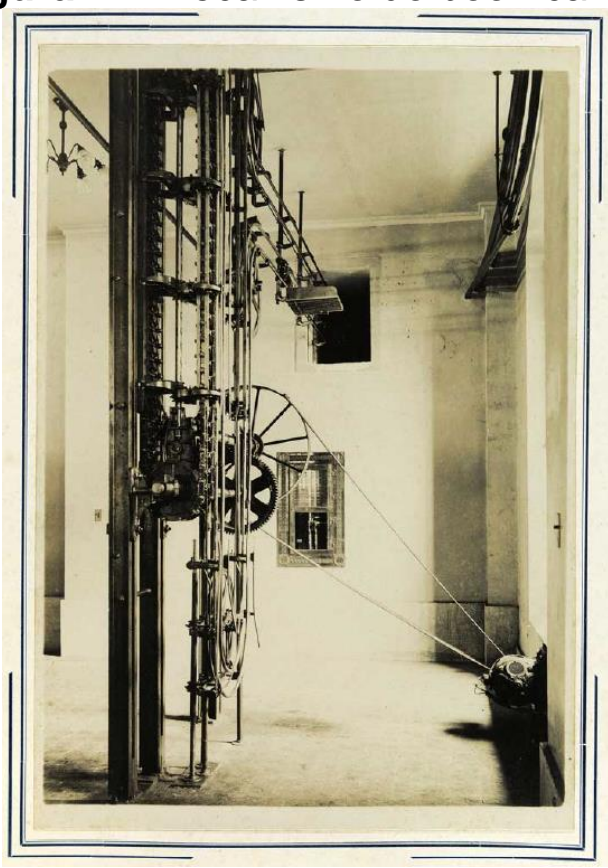

Numa espécie de sumário da atuação de Peregrino da Silva à frente da BN, Otavio (1911, p.785) escreve para a revista Illustração Portugueza o artigo "O Brasil Moderno: 
a Bibliotheca Nacional do Rio de Janeiro", cujo início já denota o apreço pela Instituição e a visão que dela tinham: "A Biblioteca Nacional, instalada no seu suntuoso palacio da Avenida Central, é uma das mais admiraveis instituições do Brazil". Continua ele sua apologia à Instituição, declarando que:

[...] Como edificio e instalação a Biblioteca Nacional do Rio de Janeiro é das primeiras do mundo. O palacio ao par de uma grandiosa aparência, bela e sobria, é dotado de todos os melhoramentos mais aperfeiçoados nos estabelecimentos do genero.

Construido de cimento e ferro, toda a sua mobilia é de aço esmaltado (OTÁVIO, 1911, p.788).

No tripé em que nos apoiaremos, o primeiro elemento a ser tratado é o espaço que a Nacional recebe; é graças ao novo prédio que ela pode implementar várias de suas ações, e Rodrigo Otavio, autor do artigo citado acima, faz sua apologia à Biblioteca exaltando esse espaço, nomeando-o de palácio e descrevendo-o em suas minúcias. Membro-fundador da Academia Brasileira de Letras, compreende bem o papel que a Biblioteca desempenhava no período, chamando atenção, ainda, para a liderança exercida por Peregrino da Silva.

A revista Illustração Portugueza, onde o artigo fora publicado, é uma revista que buscava trazer ao público lusitano o que de mais moderno havia no mundo, premissa universal nas primeiras décadas do século XX.

Figura 1 - Página do periódico Illustração Portugueza.

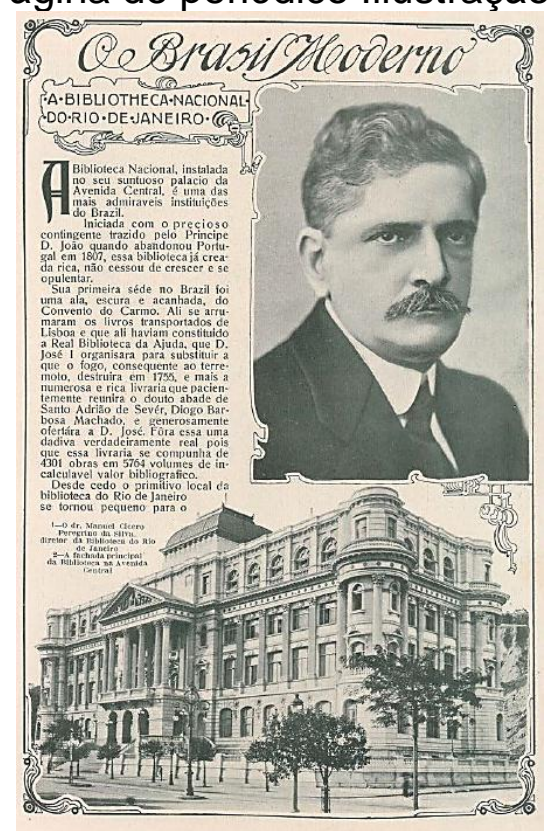

Fonte: Otavio (1911, p.785). 


\section{BIIOIOS E-ISSN 2236-7594}

Otavio (1911, p.790) ainda prossegue, observando que:

Muito ha ainda a esperar da sua competencia e disposição para o trabalho. Com o novo regulamento que acaba de ser dado á biblioteca serviços novos foram creados, por inspiração do dr. Manuel Cicero, e ele melhor do que ninguém está apto para presidir ao desenvolvimento, a que sob os novos moldes, póde chegar a biblioteca do Rio de Janeiro.

De fato, Peregrino da Silva, em seu discurso de inauguração do prédio, já prevê a responsabilidade da Nacional em honrar aquele palácio, um monumental edifício (SILVA, 1911). E seria por meio de um novo regulamento que isso se tornaria possível.

Logo, a dimensão do moderno expresso pela BN é pelo tratamento biblioteconômico e pelos serviços oferecidos por ela. Fonseca (1973) declara que tal dispositivo, publicado em 1911, era o mais moderno do período para uma biblioteca e evidencia as diversas transformações por que a Instituição passou. Num momento em que o país buscava ser reconhecido como "civilizado" e moderno, o exterior era a inspiração; nesse sentido, a Biblioteca buscou se engajar em iniciativas internacionais, relacionadas à difusão da informação.

O primeiro deles foi com a criação do Serviço de Bibliographia e Documentação, que em correspondência com o Instituto Internacional de Bibliografia (IIB) fundado por Paul Otlet e Henri La Fontaine, adquiriu fichas do Repertório Bibliográfico Universal (RBU) e as disponibilizou para consulta ao público, além de incentivar a adoção das técnicas de tratamento documental professadas pela dupla belga, como a adoção da Classificação Decimal Universal (CDU) e a busca por um padrão internacional para a catalogação dos itens.

Outra iniciativa nesse sentido foi a centralização do intercâmbio de instituições nacionais com instituições estrangeiras, por meio do Serviço de Permutas Internacionais, com a qual se conseguia obras estrangeiras para compor o acervo das instituições brasileiras e podia-se enviar obras nacionais para o exterior, sobretudo aquelas que faziam propaganda do governo, como os relatórios das instituições.

Ainda como parte da interação com ao IIB, a BN passa a editar a bibliografia brasileira, chamada de Boletim Bibliographico da Bibliotheca Nacional do Rio de Janeiro, de acordo com os padrões estabelecidos pelo Instituto belga como uma forma de colaborar com o Repertório Bibliográfico Universal ao mesmo tempo em que inventariava a produção intelectual nacional e dela fazia propaganda no exterior. Além disso, construía um importante mapa da ciência e da cultura brasileiras expressas nos registros escritos. 
Nessa mesma linha, segue a aprovação da Lei de Depósito Legal (LDL), de alcance nacional, que, pela primeira vez, alcançava todos os entes federados do país e buscava enriquecer o acervo da BN, oferecendo aos intelectuais que a circundavam o moderno em termos de produção bibliográfica.

Tais intelectuais ainda contavam com o Serviço de Informações, que visava oferecer aos usuários da BN instruções para além do acervo da Instituição, como orientações a respeito de onde pesquisar ou onde conseguir a informação que deseja.

Por falar em outras instituições, vários funcionários da Biblioteca e pessoas contratadas foram incumbidas de buscar por documentos de relevo para a história nacional e para o seu acervo em instituições brasileiras de outros estados ou no exterior, providenciando cópias a serem remetidas à $\mathrm{BN}$, uma espécie de protótipo do projeto resgate ${ }^{8}$.

A criação do curso de Biblioteconomia na Instituição talvez seja o elemento mais interessante na incorporação do moderno. Ortega y Gasset (2006) prenunciam que o bibliotecário, como profissional formado e institucionalizado, surge por vontade do social, por uma demanda que ele deve resolver, no caso, a demanda por informação organizada e acessível. Quando Peregrino da Silva vai ao exterior, ele tem contato com instituições de diferentes países e nelas, para além da técnica, observa a necessidade de formação de um profissional apto à diversidade documental e ao tamanho do acervo da Nacional:

Sem a convicção de que the corre o dever de produzir uma somma apreciavel de trabalho, de que para outro fim não foi admittido e não é mantido, de que de outro modo se transforma em pensionista e se reduz a verdadeiro parasita, sem essa nitida comprehensão, o empregado de bibliotheca é, não só uma perfeita inutilidade, mas um estorvo ao engrandecimento, ao progresso da instituição (SILVA, 1913, p.4).

Nominado como funcionário público exemplar, a serviço do Estado, Peregrino da Silva reveste a Instituição com seus ideais, colocando-a no rumo do progresso prenunciado na bandeira nacional.

Por fim, a última dimensão que nos é cara é a reunião da elite intelectual do período ao redor da BN. Se o palácio era uma expressão visual do moderno, seu acervo, produtos e serviços eram o atrativo. Eram os intelectuais que levavam à Biblioteca e dela demandavam as diversas discussões em voga no período, perfazendo nossa terceira

8 O Projeto Resgate visa "[...] disponibilizar documentos históricos relativos à História do Brasil existentes em arquivos de outros países, sobretudo Portugal e demais países europeus com os quais tivemos uma história colonial imbricada" (UNIVERSIDADE DE BRASÍLIA, [201-]). 
dimensão, tornando-a um espaço de sociabilidade. Peregrino da Silva estabelece no regulamento de 1911:

Art. 138. Haverá uma sala destinada a conferencias que poderão realizar-se mediante permissão do director geral, ou que este promoverá, escolhendo neste caso os assumptos sobre que devam versar e convidando as pessoas que dellas se tenham de encarregar.

Art. 139. arbitrada uma contribuição pelo uso da sala de conferencias sempre que, não tendo estas um fim patriotico ou beneficente, forem pagas as respectivas entradas.

Art. 140 sala não poderá ser utilizada para conferencia de caracter politico ou religioso, nem para quaesquer solemnidade que não forem promovidas pela Bibliotheca ou autorizadas pelo ministro (BRASIL, 1911).

Nesse sentido, proferem conferências entre 1911 e 1916, 36 pessoas (Quadro 1), sobre os temas mais diversos, como literatura, arte, economia, sociologia, história, etnografia, medicina, folclore, direito, física, língua portuguesa, filosofia e política.

\begin{tabular}{|c|c|c|}
\hline ANO & TÍTULO DA CONFERÊNCIA & PALESTRANTE \\
\hline \multirow{5}{*}{1911} & Nossa evolução Literária & José Veríssimo \\
\hline & Arte e bom gosto no Brasil & Roberto Gomes \\
\hline & Brasil e seu desenvolvimento econômico & Pandiá Calógeras \\
\hline & Meio social brasileiro & Conde de Affonso Celso \\
\hline & O Brasil no concerto das nações & Hélio Lobo \\
\hline \multirow[b]{2}{*}{1912} & $\begin{array}{l}\text { Da remodelação por que passou a Bibliotheca Nacional e } \\
\text { vantagens d'ahi resultantes }\end{array}$ & Manoel Cícero Peregrino da Silva \\
\hline & $\begin{array}{l}\text { História da Civilização, sua origem, processos e } \\
\text { desenvolvimento do mundo antigo; do homem primitivo; } \\
\text { de Sumeriano-Akardiano; dos Hiksos, Egito, Assíria } \\
\text { (12 conferências em francês) }\end{array}$ & Padre F. A. Deiber \\
\hline \multirow{8}{*}{1913} & Os nossos diplomatas & Oliveira Lima \\
\hline & Aborígenes e etnógrafos & Roquete Pinto \\
\hline & Os sertões brasileiros & Alberto Rangel \\
\hline & O culto e a forma na poesia brasileira & Alberto de Oliveira \\
\hline & Conquista da medicina brasileira & Dias de Barros \\
\hline & Os nossos financistas & Leopoldo Bulhões \\
\hline & Folclore, métodos e pesquisa (curso) & João Ribeiro \\
\hline & Justiça e assistência, novos horizontes & Ataulfo de Paiva \\
\hline \multirow[b]{2}{*}{1914} & $\begin{array}{l}\text { O Direito Positivo e a sociedade internacional (princípios } \\
\text { fundamentais do direito internacional privado) (série de } \\
\text { cinco conferências) }\end{array}$ & Rodrigo Otávio \\
\hline & $\begin{array}{l}\text { Da constituição da matérias, os átomos } \\
\text { Evolução e transformação da matéria } \\
\text { Matéria e energia } \\
\text { Energética e suas leis } \\
\text { Do radium } \\
\text { Dos corpos radioativos } \\
\text { Da física dos elétrons } \\
\text { Da radioatividade } \\
\end{array}$ & Oscar de Sousa \\
\hline
\end{tabular}




\begin{tabular}{|c|c|c|}
\hline ANO & TÍTULO DA CONFERÊNCIA & PALESTRANTE \\
\hline \multirow{7}{*}{1914} & $\begin{array}{l}\text { O Direito no Brasil. Sua feição particular. Seus grandes } \\
\text { intérpretes }\end{array}$ & Clóvis Bevilacqua \\
\hline & Vida econômica e financeira do país & Amaro Cavalcante \\
\hline & Aspectos do humor na literatura nacional & Afrânio Peixoto \\
\hline & O purismo e o pregresso da língua portuguesa & Said Ali \\
\hline & A medicina e os clássicos & Aloísio de Castro \\
\hline & $\begin{array}{l}\text { Bergson e a teoria do conhecimento; Bergson e o } \\
\text { princípio da liberdade }\end{array}$ & $\begin{array}{l}\text { Esmeraldino Bandeira } \\
\text { Miguel Pereira } \\
\text { José de Mendonça } \\
\text { Araújo Viana } \\
\text { Farias de Brito }\end{array}$ \\
\hline & $\begin{array}{l}\text { Amerique } \\
\text { L'espirit des republiques latines } \\
\text { Le genie latin dans l'art et la literature } \\
\text { La solidarieté des nations }\end{array}$ & Leopold Mabilleau $^{9}$ \\
\hline \multirow{4}{*}{1915} & Algumas doenças causadas por protozoários & Oswaldo Cruz \\
\hline & Parlamentarismo e presidencialismo & Aureliano Leal \\
\hline & O ensino do Direito no Brasil & Castro Rebelo \\
\hline & $\begin{array}{l}\text { Nos catredales au point de vue des idées sociales et } \\
\text { democratiques }\end{array}$ & Charles Cahrnaux \\
\hline \multirow{4}{*}{1916} & Sobre algumas lendas do Brasil & Olavo Bilac \\
\hline & O ensino médico no Brasil & Olímpio da Fonseca \\
\hline & $\begin{array}{l}\text { O que foi o Conselho de Estado no Império e o que } \\
\text { poderia ser na República }\end{array}$ & Sousa Bandeira \\
\hline & Adoção de um padrão monetário no Brasil & Homero Pires \\
\hline
\end{tabular}

Fonte: Juvêncio (2016).

Peregrino esclarece que:

A escolha das pessoas encarregadas de explanar e desenvolver esses themas merecerá, certamente, o applauso dos que se dignatem a de honrar com a sua presença as conferencias que a Bibliotheca promove. São nomes feitos no nosso meio intellectual que virão dar brilho e realce ás recepções desta casa (SILVA, 1913, p.9).

Ao passo que Bittencourt (1955, p.80-81) sublinha que "Manuel Cícero reuniu em tôrno da Biblioteca a elite intelectual mais apurada [...]. Criou um ambiente próprio para a cultura histórica que se intensificava no Brasil". Dessa forma "[...] estreita ou ata relações com quem já conhecia e com quem veio a conhecer. Êle estava pois em contato com o que havia de mais expressivo no meio intelectual brasileiro".

Oliveira Lima, citado por Bittencourt (1955), observa, em dois momentos distintos, a atuação de Peregrino. No primeiro, destaca, com relação às conferências na Biblioteca Nacional, que:

${ }^{9}$ Conferências proferidas a pedido do Comité Français (BITTENCOURT, 1955, p.76). 


\section{BIDIOS E-ISSN 2236-7594}

Manuel Cícero nutre a nobre ambição de dotar a sua, a nossa biblioteca, de um maior alcance social, convertendo êsse repositório e o passivo de edições raras, de obras monumentais e manuscritos preciosos, num centro ativo de educação do gôsto literário e artístico da nossa população (LIMA apud BITTENCOURT, 1955, p.77).

Assim, exprime-se o papel da BN como núcleo angariador das discussões de relevo para o país e o que estava em voga como moderno no período.

\section{CONCLUSÃO OU CONSIDERAÇÕES FINAIS}

Lima Barreto (2017), em 1915, escrevia sobre a Biblioteca Nacional:

A diretoria da Biblioteca Nacional tem o cuidado de publicar mensalmente a estatística dos leitores que a procuraram, das classes de obras que eles consultam e da língua que as mesmas estão escritas.

Pouco frequento a Biblioteca Nacional, sobretudo depois que se mudou para a Avenida e ocupou um palácio americano.

A minha alma é de bandido tímido, quando vejo desses monumentos, olho-os, talvez, um pouco, como um burro; mas, por cima de tudo, como uma pessoa que se estarrece de admiração diante de suntuosidades desnecessárias.

[...].

O Estado tem curiosas concepções, e esta, de abrigar uma casa de instrução, destinada aos pobres-diabos, em um palácio intimidador, é das mais curiosas.

[...].

A velha biblioteca ${ }^{10}$ era melhor, mais acessível, mais acolhedora, e não tinha a empáfia ${ }^{11}$ da atual.

De fato, a visão crítica e apurada de Lima Barreto sobre as mudanças por que a cidade passava, no início do século XX, é-nos cara, o palácio foi construído para opor e consagrar o grau de civilização de uma Nação que há pouco tempo era o único país do ocidente a permitir a escravidão. A dicotomia entre a barbárie escravagista e a civilização monumental explica o porquê das escolhas da República, afastar a herança, que era portuguesa e não brasileira.

As estatísticas, citadas pelo escritor, são uma forma de propaganda, de justificar o investimento e de mostrar que também há no país uma elite intelectual, uma cidade das letras, à moda parisiense. Como bem evidencia Lima Barreto, tal reforma foi realizada para as elites intelectuais e dominantes do período, uma forma de agradá-los face ao ar

10 Situada na Rua do Passeio, era sede da BN desde 1858, hoje, abriga a Escola de Música da Universidade Federal do Rio de Janeiro (UFRJ).

11 "1. Orgulho afetado, manifestação ou atitude de suposta superioridade; ARROGÂNCIA; INSOLÊNCIA; SOBERBA" (AULETE, [2013]). 
moderno que a capital ganhava. Uma modernidade, obviamente, importada, afinal, como observa Gomes (1983, p.84):

As bibliotecas brasileiras da Primeira República [...] refletiram também a condição de dependência. Reuniram, conservaram e difundiram, limitadamente e de modo reflexo, a cultura estrangeira. Baseavam-se nos mesmos padrões, compostas de livros que eram veículos de uma cultura erudita importada, fundamentada nos ideais humanistas de desenvolver as virtualidades do homem. Eram acanhados repositórios de produtos acabados do corpo ideológico da cultura alheia, consideradas insígnias do homem culto e superior.

Não havia espaço para o Brasil de Lima Barreto, somente para o Brasil idealizado pelas elites, da velha ancestralidade europeia e que comportava os estudos mais modernos, mas rechaçava as suas raízes, o moderno, aqui, não é o mesmo moderno dos Modernistas de 1922, ainda é o moderno olhando para fora, em que o uso de fraque no verão carioca era explicado pela moda.

Gomes (1983, p.85) prossegue alertando que:

Essas bibliotecas, como agências de instituições sociais de uma sociedade subdesenvolvida e dependente, atenderam às necessidades de segmentos dessa sociedade. Com seu caráter elitista, decorrente dessa situação, serviram, assim como a educação, instituição a que estiveram mais ligadas na República Velha, de meio de promoção social e aperfeiçoamento pessoal.

A ideia era mostrar como que aquela civilização da barbárie escravagista havia sido superada, o moderno havia chegado e afastado a herança indesejada, mas a que custo? Os casarões arrasados no Centro da cidade eram a moradia de pessoas mais humildes, que perderam espaço e foram confinadas aos subúrbios da cidade, longe da vista. Seus antigos terrenos foram alvo de especulação imobiliária e vendidos a preços exorbitantes.

Nesse bojo, a Biblioteca Nacional junta ao seu redor a elite do período, servindo ao propósito de fazê-la se sentir nos salões de discussões europeus e estadunidenses, importando mentes para que proferissem conferência sobre os temas modernos ou convocava os brasileiros que lá estiveram e experimentaram da civilização modelo a divulgar as suas impressões e os seus estudos.

Discussões políticas e religiosas só eram permitidas se abordassem o campo teórico da questão, uma tentativa de laicização do Estado. O moderno para a Biblioteca Nacional realmente resultou em transformações profundas, mas que serviam a poucas pessoas, talvez por isso a dificuldade, após a gestão de Peregrino da Silva, em manter tais serviços funcionando e nos holofotes das ações governamentais. 
Juvêncio e Rodrigues (2018) observam que, após a ascensão de Getúlio Vargas ao poder, em 1930, o papel da BN é ofuscado pelo do Instituto Nacional do Livro, mas, antes mesmo, o papel das bibliotecas começa a esmorecer frente a um mundo em guerra. Bessone (1999, p.117-118) observa que:

[...] todas as dificuldades inerentes à ampliação dos seus universos culturais, como a parca renovação de títulos nas mais prestigiadas bibliotecas, em face dos limitados recursos financeiros das instituições, à dependência em relação a doadores e mecenas, e à ausência de uma política eficiente de atualização científica (BESSONE, 1999, p.117-118).

Assim, mesmo sendo um polo de atração intelectual, as bibliotecas tinham dificuldade de aumentar seus acervos e de se manterem, prova disso é que, em 1916, a Biblioteca Fluminense perece. Caracterizada como uma biblioteca privada franqueada ao público, ela era mantida por seus entusiastas, que, com o tempo, ficaram raros. Fechada, seu acervo é integralmente incorporado à Nacional.

$\mathrm{Na}$ dinâmica do mecenato citado por Bessone (1999), a Nacional novamente serve ao propósito, já que a doação tem um duplo papel: enriquecer o acervo da Instituição, mas perpetuar os beneméritos com a inscrição na memória nacional. Otavio (1911) cita dois bons exemplos:

Ainda recentemente recebeu a Biblioteca dois presentes reaes: uma rica
livraria do finado diplomata Ferreira da Costa constando de mais de
8000 volumes, especialmente referentes a belas artes; outra famosa
biblioteca brazileira do dr. José Carlos Rodrigues adquirida pelo opulento
industrial dr. Benedito Atoni ${ }^{12}$ [sic] para ofertar á Biblioteca. A preciosa
livraria do dr. Rodrigues consta de mais de 12 mil numeros e compreende
manuscritosrd [sic] e muito valor, impressos, dos quaes muitos de extrema
raridade, cartas geograficas, estampas e retratos, tudo referente ao Brazil,
proxima ou remotamente (OTAVIO, 1911, p.788).

Um diplomata e dois empresários, as elites utilizam o espaço nacional para a sua perpetuação e da sua memória, atuando, significativamente, no campo simbólico.

Como vimos, a BN, ao se mudar para um monumental palácio, figura dentre os símbolos do Brasil civilizado e seu caráter é exaltado: guardiã da memória nacional ou uma memória das elites? Além de oferecer o moderno através de seus produtos e serviços e ser um polo de erudição em busca do desejo de civilização e de modernidade da Primeira República.

\footnotetext{
$12 \mathrm{O}$ correto seria Otoni.
} 


\section{REFERÊNCIAS}

AULETE, Caldas. I Dicionário Aulete. Rio de Janeiro: Lexikon, [2013].

BARRETO, Lima. Cronista do Rio. Rio de Janeiro, Belo Horizonte: Biblioteca Nacional, Autêntica, 2017.

BESSONE, Tania Maria. Palácios de destinos cruzados: bibliotecas, homens e livros no Rio de Janeiro : 1870-1920. Rio de Janeiro: Arquivo Nacional, 1999.

BIBLIOTECA DA PRESIDÊNCIA DA REPÚBLICA. Biografia de Epitácio Pessoa. [Brasília: Presidência da República], c2015. Disponível em: http://www.biblioteca.presidencia.gov.br/expresidentes/epitacio-pessoa/biografia. Acesso em: 10 out. 2020.

BIBLIOTECA NACIONAL. Album de photographias. Rio de Janeiro: Biblioteca Nacional, 1911. Disponível em: http://objdigital.bn.br/acervo_digital/div_iconografia/icon393014/icon393014.pdf. Acesso em: 20 out. 2020.

BITTENCOURT, Feijó. Vida de Manuel Cícero Peregrino da Silva. Revista do Instituto Histórico e Geográfico Brasileiro, v.229, out./dez. 1955.

BORGES, Dayane. Belle Époque, o que foi? Definição, característica e cultura do divertimento Conhecimento Científico, 07 set. 2020. Disponível em:

https://conhecimentocientifico.r7.com/belle-epoque/. Acesso em: 07 nov. 2020.

BRASIL. Decreto n.8.835, de 11 de Julho de 1911: Approva o regulamento da Bibliotheca Nacional. Diário Oficial da União, 16 jul. 1911. Disponível em:

http://www2.camara.leg.br/legin/fed/decret/1910-1919/decreto-8835-11-julho-1911-502890republicacao-102224-pe.html. Acesso em: 01 nov. 2020.

CARVALHO, José Murilo de. A formação das almas: o imaginário da república no Brasil. São Paulo: Cia. das Letras, 2011.

ENDERS, Armelle. Os vultos da nação: fábrica de heróis e formação dos brasileiros. Rio de Janeiro: FGV, 2014.

FONSECA, Edson Nery da. Origem, evolução e estado atual dos serviços de Documentação no Brasil. Revista do Serviço Público, Brasília, v.108, n.1, p.37-52, jan./abr. 1973.

FUNDAÇÃO OSWALDO CRUZ. Oswaldo Cruz. Rio de Janeiro: FIOCRUZ, c2000. Disponível em: http://www.ioc.fiocruz.br/pages/personalidades/OswaldoGoncalvesCruz.htm. Acesso em: 16 out. 2020.

GOMES, Sônia de Conti. Bibliotecas e sociedade na Primeira República. [Brasília]: INL, 1983. JUVÊNCIO, Carlos Henrique. Manoel Cícero Peregrino da Silva, a Biblioteca Nacional e as origens da Documentação no Brasil. 2016. 2v., il. Tese (Doutorado em Ciência da Informação) - Universidade de Brasília, Brasília, 2016.

JUVÊNCIO, Carlos Henrique; RODRIGUES, Georgete Medleg. The Modern and its impact on models of information organization in Brazil: the decline of the National Library and the rise of the National Book Institute (1930-1954). In: ISKO CONFERENCE, 15., 2018,

Porto. Challenges and Opportunities for Knowledge Organization in the Digital Age. Alemanha: Ergon, 2018. v.16. p.356-362.

KOK, Glória. Rio de Janeiro na época da Av. Central. São Paulo: Bei Comunicação, 2005.

LAEMMERT, Eduardo. Almanak administrativo, mercantil e industrial do Rio de Janeiro. Rio de Janeiro, 1893. Disponível em: http://bndigital.bn.br/acervo-digital/almanak-administrativomercantil-industrial-rio-janeiro/313394. Acesso em: 21 out. 2020.

LATOUR, Bruno. Redes que a razão desconhece: laboratórios, bibliotecas, coleções.

In: BARATIN, Marc; JACOB, Christian. O poder das bibliotecas: a memória dos livros no ocidente: Rio de Janeiro: UFRJ, 2008. 
NEVES, Margarida de Souza. Os cenários da república: o Brasil na virada do século XIX para o século XX. In: FERREIRA, Jorge; DELGADO, Lucila de Almeida Neves. 0 tempo do liberalismo excludente: da Proclamação da República à Revolução de 1930. Rio de Janeiro: Civilização Brasileira, 2003. (O Brasil Republicano; 1).

ORTEGA Y GASSET, José. Missão do bibliotecário. Brasília: Briquet de Lemos, 2006.

OTAVIO, Rodrigo. O Brasil Moderno: A Bibliotheca Nacional do Rio de Janeiro. Illustração

Portugueza: revista semana dos acontecimentos da vida portuguesa, 2a. série, v.11, 2. sem. 1911.

PALMA, Ana. Oswaldo Cruz. In Vivo, [200-]. Disponível em:

http://www.invivo.fiocruz.br/cgi/cgilua.exe/sys/start.htm?infoid=114\&sid=7. Acesso em: 07 nov. 2020.

RAMA, Angel. A cidade das letras. São Paulo: Brasiliense, 1985.

SACRAMENTO BLAKE, Augusto Victorino Alves. Diccionario Bibliographico Brazileiro (v.1-7).

Rio de Janeiro: Typographia Nacional, 1893-1902. Disponível em:

https://www2.senado.leg.br/bdsf/handle/id/221681. Acesso em: 01 nov. 2020.

SCHWARTZMAN, Simon. Um espaço para a ciência: a formação da comunidade científica no

Brasil. Brasília: Ministério da Ciência e da Tecnologia, 2001. (Coleção Brasil, Ciência e

Tecnologia; 1).

SILVA, Manoel Cícero Peregrino da. A Bibliotheca Nacional em 1910. Annaes da Bibliotheca

Nacional do Rio de Janeiro, v.33, p.367-397, 1911.

SILVA, Manoel Cícero Peregrino da. Da remodelação por que passou a Bibliotheca Nacional e vantagens d'ahi resultantes. Annaes da Bibliotheca Nacional do Rio de Janeiro, v.35, p.1-9, 1913.

UNIVERSIDADE DE BRASÍLIA. Centro de Memória Digital. Histórico do Projeto Resgate. Brasília: UnB, [201-]. Disponível em: http://www.cmd.unb.br/resgate_index.php. Acesso em: 07 nov. 2020. 